\title{
Cash Position Forecasts Pre and Post the 2008 Market Crash
}

\author{
Richard L. Alltizer \\ University of Central Oklahoma • Edmond, OK \\ Zane L. Swanson \\ University of Central Oklahoma • Edmond, OK
}

\section{$\overline{\text { ABSTRACT }}$}

Our study focuses on the important issue of cash forecasting. The Wall Street Journal (WSJ) published articles $(1995,2009)$ dealing with the record levels of cash held by large publicly traded companies, asserting that cash positions may be excessive. The articles discuss, at points in time, a trend over three decades of increasing cash holdings which doubled from 1980 through 2006. The ability to forecast cash holdings is an important element in deciding where to invest consistent with one's predilection, and may therefore become more important as cash holdings increase. In contrast to prior research, our study demonstrates a forecasting model with firm-specific variables. The results indicate a strong model in spite of changing economic conditions; however, with significant turbulence (i.e. the 2008 market failure), we find that certain coefficients are impacted.

\section{DATA AVAILABILITY}

Data used in this study are available from public sources identified in the study.

\section{INTRODUCTION}

While it is generally agreed that there is not a "right answer" as to how much cash a firm should carry (Opler et al., 1999), it is also generally agreed that practitioners find both the amount of cash a firm is carrying and the ability to accurately forecast cash holdings information that matters. Basic financial theory holds that sitting on cash has a significant opportunity cost that may indicate either a lack of opportunity in an industry or the inability of management to find productive investment choices (Grinblatt and Titman, 2001). However, there is some fairly strong empirical evidence that, as a general rule, a firm's investment behavior is a function of cash availability (Fazzari, Hubbard, and Petersen, 1988). An obvious corollary is 
that a firm with large amounts of cash that does not invest sees no opportunity and consequently growth cannot be reasonably anticipated by an investor.

Basic agency theory would also suggest that management in firms sitting on large amounts of cash are far less incentivized to turn in optimal performance, and that large amounts of debt, that must be serviced, does tend to generate the best performance from management. It is also arguable that the financial crisis of 2008 produced an intercept shift in the corporate world's faith in financial markets and thus attitudes changed towards holding large amounts of cash. Irrespective of which of the above views is correct, in light of the financial crisis and the demonstrated importance of cash flow concerns to investors, the issue is worth revisiting. In addition, prior research (Bates et al., 2009) demonstrates that firm value is positively associated with firm cash positions. In summary, the ability to accurately forecast cash impacts both investors and management.

Analyst and other information services (e.g. Value Line) provide cash flow forecasts for large and medium sized firms which are used in the valuation process. Anecdotal information indicates firm cash positions have been increasing which may complicate an assessment of the appropriate holding of cash. Our Figure 1 illustrates an increasing trend in the ratio of cash holdings to total assets. From 1980, the ratio of cash to total assets has increased dramatically before trending back down in the mid-2000s (the ratio was 12.59 percent in 1980 and averaged 18.58 percent in the period 2000 to 2006).

\section{Figure 1}

Thirty Year Summary of Cash to Total Assets

\section{Cash Holdings History}

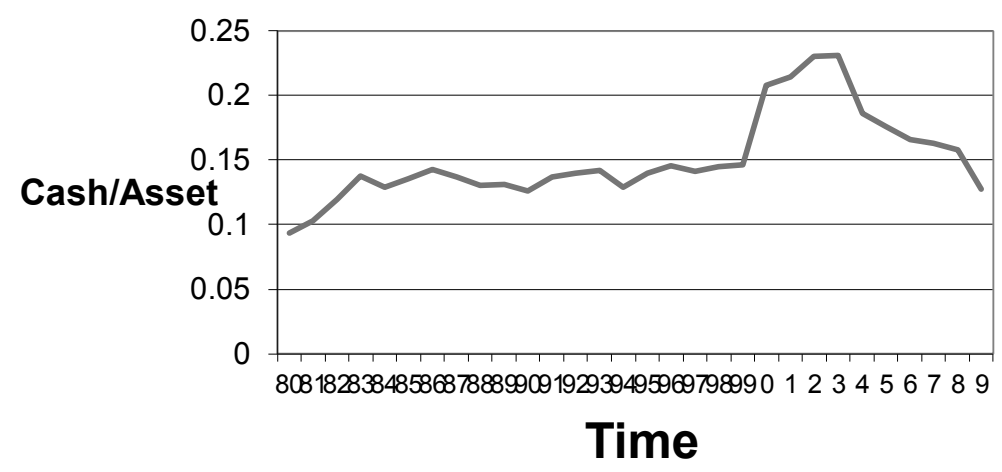


Certainly, if companies are hoarding cash, the economic uncertainty of the last decade may have a further adverse effect on forecasting. In their study, Kim et al. (1998) offer two possible explanations as justification for increased holdings of liquid assets. They contend that when companies are faced with volatile earnings reports and/or relatively lower returns on assets the ratio of cash holdings increases. The decade of the 2000s was a period of economic turmoil which may contribute to the increase in cash ratios.

This study utilizes a model that is historically effective in forecasting a firm's cash position from 1980 through 2006. We posit that during periods of extreme economic uncertainty, the model and/or the independent variables may shift in importance as conditions change. Thus, investors may have difficulty using cash forecasting data in their investment decisions during periods of uncertainty in the financial markets. Given the importance of cash forecasting, the present study extends prior research by analyzing the ability to forecast cash during periods of economic uncertainty. To investigate this proposition, we study the 2008 market crisis.

The remainder of the paper is organized as follows: The next section reviews the relevant literature. The methodology section follows and includes a description of the sample. Next we present the empirical results, and the final section contains our conclusions.

\section{PRIOR LITERATURE}

Firm accumulation of cash is not a new phenomenon. Reinhardt (1997) noted there were increasing amounts of cash accumulation. Again, in 2009, the WSJ (Zwieg) reported that corporate cash umbrellas were quite large and perhaps too large. While the WSJ articles discuss points in time and our study investigates a period of time, we reference their articles to note the perceived importance of cash holdings. Bates et al. (2009) reported a 100 percent increase in the cash to total asset ratio for a sample of industrial firms between 1980 and 2006. Bates concluded that firms tend to increase the ratio of their cash holdings as their cash flows become riskier.

Corporate cash holding is the subject of a considerable body of literature, and while most of the literature deals with levels of cash (e.g. Reinhardt, 1997) some have dealt with cash forecasting (Ozkan and Ozkan, 2004). Both lines of research employ variables relevant to cash forecasting. We draw from both types of studies in developing our cash forecasting model.

Morris (1983) developed a theoretical basis for the use of cash holdings to explain firm value. Thus, forecasting cash positions is an important element in pre- 
dicting firm value. Bates et al. (2009) examined data from the 1980s to 2006 and employed a predictive model based on four self-selected motives: transactions, precautionary, tax and agency. The transaction motive is based on utilizing economies of scale where noncash financial assets are converted into cash to support operating expenses. To mitigate risk, firms will tend to hold greater amounts of cash as a precaution against adverse events. The tax motive involves primarily multinational firms and the repatriation of foreign earnings. Their actions suggest that companies minimize repatriation to maximize cash holdings by avoiding taxation on foreign earnings. The agency motive (Jensen, 1986) predicts that firms with entrenched management will tend to hold more cash when faced with poor investment choices in lieu of payments to investors.

Our study utilizes data from the periods 1980-1989, 1990-1999 and 20002006 to establish the validity of our model, we then extend the analysis through 2007-2009. The primary focus of our study, after establishing a base case by period, is the period around the 2008 market crash (2007, 2008 and 2009).

In contrast to Bates et al. (2009) and others, our structured model is based on a cash flow statement approach developed by Vickrey and Swanson (1996). The cash flow statement describes the change in cash holdings from period t- 1 to period $\mathrm{t}$; therefore, we have a theoretically sound basis for the selection of our variables. In keeping with a cash flow statement approach, the present study includes firm specific variables representing the operating cycle of cash flows, long-term asset affects and a leverage variable.

Bates et al. (2009) asserted that firms hold increasing amounts of cash during market stresses as a precautionary motive; accordingly they included a market-tobook ratio to test that motive. Bates found a positive association between his cash ratio (cash divided by total assets) and a market-to-book variable. Ozkan and Ozkan (2004) also found significance with a market-to-book variable in their cash forecasting study of UK firms. Therefore, based on the prior literature, we include a marketto-book variable in our forecasting model.

Ozkan and Ozkan (2004), in their forecasting study, found no linear relationship with respect to management ownership and cash projections. The present study utilizes a linear model, thus we are not including management ownership as a predictive variable.

Opler et al. (1999) developed a descriptive model for cash holding that is based on economic circumstances in the context of risk and management utility functions. Their economic reasons (note similarities to Bates et al., 2009) included: (1) a responsibility to pay obligations, (2) holdings to invest in business opportuni- 
ties and (3) reserves for contingencies ${ }^{1}$. Alternatively, we develop a predictive model based on firm specific variables.

For the above reasons, the present study includes firm variables representing a company's operating cycle. We examine and extend the cash forecasting line of research by testing the reliability of variables affecting cash forecasting during a period of uncertainty in the financial markets. A complete description of our independent variables follows in the research methodology section.

\section{$\overline{\text { RESEARCH METHODOLOGY }}$}

\section{Hypothesis Development}

The present study investigates cash forecasting by developing a prediction model which is based on prior research (Bates et al., 2009); (Ozkan and Ozkan, 2004); and (Vickrey and Swanson, 1996). We test the model over three periods (1980s, 1990s and 2000-2006) to establish robustness. After establishing the validity of the model, we then investigate the ability to forecast cash holdings during a period of significant uncertainty in the economy. Specifically, did the 2008 market crisis impact the ability to forecast cash holdings? The formal statement of the null hypothesis is:

$\mathrm{H} 0$ : Cash forecasting is unaffected by changing economic circumstances.

\section{Regression Model}

Our study utilizes a regression model forecasting the ratio of cash to total assets at time $t$ which employs the cash flow statement approach and includes a market-to-book variable. A basic premise of our regression equation is an autoregressive model where the forecasted dependent variable is equal to the prior period's cash position (i.e. CashRatio ${ }_{t}=a_{0}$ CashRatio $_{t-1}$ ). Opler et al. (1999) tested the autoregressive theory that cash holding is mean reverting and found a significant association. The following equation utilizes an autoregressive model and incorporates firm fundamentals based on the cash flow statement approach as explained below.

$$
\begin{aligned}
& \text { CashRatio }_{\mathrm{t}}=\mathrm{a}_{0} \text { CashRatio }_{\mathrm{t}-1}+\mathrm{b}_{1} \Delta \mathrm{REC}_{\mathrm{t}-1}+\mathrm{b}_{2} \Delta \mathrm{INV}_{\mathrm{t}-1}+\mathrm{b}_{3} \Delta \mathrm{AP}_{\mathrm{t}-1}+\mathrm{b}_{4} \Delta \mathrm{CFL}_{\mathrm{t}-1} \\
& +\mathrm{b}_{5} \text { LTA }_{\mathrm{t}-1}+\mathrm{b}_{6} \text { MKTBKA }_{\mathrm{t}-1}+\mathrm{b}_{7} \mathrm{DR}_{\mathrm{t}-1}+\mathrm{e}_{\mathrm{t}}
\end{aligned}
$$


Where:

CashRatio $_{\mathrm{t}}=$ cash at time $\mathrm{t}$ divided by total assets $\left(\mathrm{ta}_{\mathrm{t}}\right)$ at time $\mathrm{t}$,

$\Delta \mathrm{REC}_{\mathrm{t}-1}=$ scaled change in receivables in year $\mathrm{t}-1$ (i.e., $\left.\left(-\mathrm{REC}_{\mathrm{t}-1}+\mathrm{REC}_{\mathrm{t}-2} / \mathrm{ta}_{\mathrm{t}-1}\right)\right)$,

$\Delta \mathrm{INV}_{\mathrm{t}-1}=$ scaled change in inventories in year $\mathrm{t}-1$ (i.e., $\left(-\mathrm{INV}_{\mathrm{t}-1}+\mathrm{INV}_{\mathrm{t}-2} / \mathrm{ta}_{\mathrm{t}-1}\right)$ ),

$\Delta \mathrm{AP}_{\mathrm{t}-1}=$ scaled change in accounts payable and accrued liabilities in year t-1 (i.e., $\left(\mathrm{AP}_{\mathrm{t}-1}-\mathrm{AP}_{\mathrm{t}-2} / \mathrm{ta}_{\mathrm{t}-1}\right)$ ),

$\Delta \mathrm{CFL}_{\mathrm{t}-1}=$ cash change in year $\mathrm{t}-1$ less $\mathrm{REC}_{\mathrm{t}-1}, \mathrm{INV}_{\mathrm{t}-1}$, and $\mathrm{AP}_{\mathrm{t}-1}$ which is then scaled by $\mathrm{ta}_{\mathrm{t}-1}$,

$\mathrm{LTA}_{\mathrm{t}-1}=\log \left(\mathrm{TA}_{\mathrm{t}-1}-\mathrm{CA}_{\mathrm{t}-1}-\mathrm{REC}_{\mathrm{t}-1}-\mathrm{INV}_{\mathrm{t}-1}\right)$,

MKTBK $_{t-1}=$ the stock market value in year $\mathrm{t}-1 /$ book value in year $\mathrm{t}-1$,

$\mathrm{DR}_{\mathrm{t}-1}=$ the long term debt in year $\mathrm{t}-1 / \mathrm{ta}_{\mathrm{t}-1}$, and

$\mathrm{e}_{\mathrm{t}} \quad=$ error in period $\mathrm{t}$.

The regression variables are explained as follows:

1) CashRatio t- $_{1}$ is included per the prior explanation of the autoregressive odel (Opler et al., 1999),

2) we then add a set of operating cycle variables as follows: $\left(\Delta \mathrm{REC}_{\mathrm{t}-1}\right)$, inventory $\left(\Delta \mathrm{INV}_{\mathrm{t}-1}\right)$ and payables $\left(\Delta \mathrm{AP}_{\mathrm{t}-1}\right)$ (Vickrey and Swanson, 1996),

3) $\Delta \mathrm{CFL}_{\mathrm{t}-1}$ is included as per Vickrey and Swanson (1996). This variable represents changes in cash due to other than operating cycle changes,

4) LTA $_{t-1}$ is included per the cash flow statement approach (Vickrey and Swanson, 1996). Theoretically, as the long-term asset holdings increase more cash is required for sustainability. A log of this variable is employed to scale it consistent with the other variables,

5) the Market-to-book ratio is representative of the cash necessary to take advantage of investment opportunities (Bates et al., 2009 and Ozkan and Ozkan, 2004) and

6) debt may be a constraining factor as firms may be required to use cash to reduce their leverage (Bates et al., 2009 and Opler et al., 1999).

In summary, a company's cash position is a function of firm fundamentals. Our model employs the cash flow statement approach (Vickrey and Swanson, 1996) including operating, financing and investing activities. Based on the prior work of Bates et al. (2009) and Ozkan and Ozkan (2004), we also include a market-to-book variable. 


\section{SAMPLE DESCRIPTION}

All Research Insight (Compustat) firms were initially eligible for the period 1980 through 2008. The financial data for 2009 was obtained from eXtensible $\boldsymbol{B}$ usiness $\boldsymbol{R}$ eporting $\boldsymbol{L}$ anguage (XBRL) filings located in the Security and Exchange Commission's (SEC) Edgar database.

We restricted our sample in several respects. Regulated firms in Standard Industrial Classifications (SIC) codes 4800 to 4899 and financial firms from SIC codes 6000 through 6999 are excluded. The reasoning is that these firms have external regulators influencing the balance sheet accounts. Furthermore, financial firms were removed because of regulatory constraints which may differentiate their investors from the rest of the market. We eliminate firms with SIC codes 9000 or greater because they are generally nonbusiness entities (e.g. public administration) with operating characteristics different from for-profit firms. SIC codes of 1000 or below are excluded because they are primarily agriculturally related firms which are influenced by commodity markets. Elimination of these firms may also reduce an element of heterogeneity which could distort our results. Only firms with positive cash balances are included in the study because firms with negative cash balances are suspected of being in financial distress. Lastly, only firms with values for all applicable variables are included in the analyses. The industry membership of our sample is shown in Table 1, and is representative of the general distribution of the firms in the stock market. Thus, our results should be generalizable.

Table 1

Industry Membership (1980 through 1999)

\begin{tabular}{|c|c|c|c|}
\hline Industry & SIC Codes & Percent & Description \\
\hline 1 & $10-19$ & 5.98 & Mining \\
\hline 2 & $20-39$ & 59.61 & Industrial \\
\hline 3 & $40-48$ & 5.38 & Transportation \\
\hline 4 & $50-51$ & 5.65 & Wholesale \\
\hline 5 & $52-59$ & 9.26 & Retail \\
\hline 6 & $70-89$ & 14.12 & Service \\
\hline
\end{tabular}




\section{EMPIRICAL FINDINGS}

We conduct an event study over the 2008 market crisis by focusing on cash forecasting over 2007, 2008 and 2009. As part of our analysis, we investigate for multicollinearity and provide a correlation table for the 2007, 2008 and 2009 data. Only one pair of correlations is greater than .5 (See Table 2). In the regressions, all variance inflation factors (VIFs) are less than 10 suggesting that multicollinearity is not present in the model.

Table 2

Pearson Correlation Coefficients, $N=4229$

For the years 2007, 2008 and 2009

(Variable definitions follow Equation (1) in the text)

\begin{tabular}{|c|c|c|c|c|c|c|c|c|c|}
\hline$\sum^{\underline{u}}$ & & & & & & & & 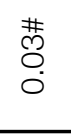 & 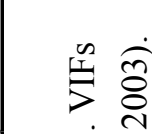 \\
\hline$\frac{1}{5}$ & & & & & & & 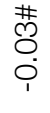 & $\begin{array}{l}\stackrel{*}{N} \\
\stackrel{0}{0}\end{array}$ & 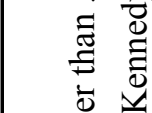 \\
\hline$\vec{I}^{I}$ & & & & & & $\begin{array}{l}L_{0}^{*} \\
0 \\
0\end{array}$ & $\begin{array}{l}\overline{0} \\
0 \\
\end{array}$ & $\begin{array}{l}\mathscr{C}_{0}^{*} \\
0 \\
0\end{array}$ & 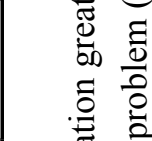 \\
\hline$\sum^{2}$ & & & & & $\begin{array}{l}\stackrel{*}{*} \\
\infty \\
0 \\
0 \\
\end{array}$ & $\begin{array}{l}* \\
0 \\
0 \\
0\end{array}$ & ¿ & $\begin{array}{l}\tilde{N} \\
\text { Oे } \\
0 \\
\end{array}$ & $\begin{array}{l}\tilde{E} \\
0 \\
0 \\
0\end{array}$ \\
\hline$z^{z}$ & & & & 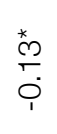 & \begin{tabular}{l}
0 \\
\multirow{0}{0}{} \\
0
\end{tabular} & $\begin{array}{l}* 0 \\
0 \\
0 \\
0\end{array}$ & $\begin{array}{l}\overline{0} \\
0 \\
\end{array}$ & $\begin{array}{l}\overline{0} \\
0\end{array}$ & 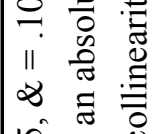 \\
\hline 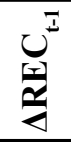 & & & $\stackrel{*}{\stackrel{*}{N}}$ & 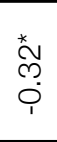 & $\begin{array}{l}\text { êं } \\
\text { m. } \\
0\end{array}$ & $\stackrel{\stackrel{*}{m}}{\stackrel{0}{\circ}}$ & $\begin{array}{l}\text { ô } \\
\text { o. }\end{array}$ & $\begin{array}{l}\text { \% } \\
0 \\
0\end{array}$ & 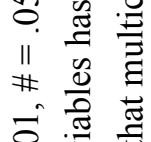 \\
\hline 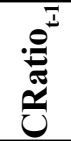 & & $\begin{array}{l}\overline{0} \\
0 \\
\end{array}$ & ${ }^{*}$ & $\begin{array}{l}\overline{0} \\
\circ \\
0\end{array}$ & $\begin{array}{l}\infty \\
0 \\
0 \\
0 \\
1\end{array}$ & $\begin{array}{l}\text { ó } \\
\stackrel{0}{0} \\
\text { i }\end{array}$ & $\begin{array}{l}8 \\
0 \\
1\end{array}$ & $\begin{array}{l}\infty \\
\stackrel{1}{1} \\
0 \\
1\end{array}$ & 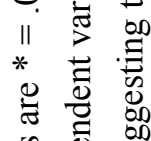 \\
\hline 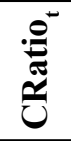 & $\begin{array}{l}\stackrel{*}{\infty} \\
\infty \\
0 \\
0\end{array}$ & $\begin{array}{l}\bar{\sigma} \\
\\
\end{array}$ & $\begin{array}{l}\text { to } \\
0 \\
0\end{array}$ & $\begin{array}{l}0 \\
0 \\
0 \\
0\end{array}$ & 芳 & \begin{tabular}{l}
$*$ \\
\multirow{0}{*}{} \\
$\stackrel{0}{0}$ \\
0
\end{tabular} & $\begin{array}{l}8 \\
\text { i }\end{array}$ & $\begin{array}{l}\stackrel{0}{0} \\
0 \\
1\end{array}$ & 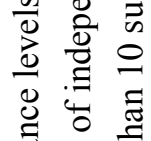 \\
\hline$\frac{0}{\frac{0}{0}}$ & $\begin{array}{l}\stackrel{\circ}{ \pm} \\
\stackrel{5}{\pi} \\
\frac{\pi}{0}\end{array}$ & 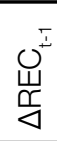 & $\varliminf^{I}$ & $\frac{q^{5}}{4}$ & $\frac{\vec{J}}{0}$ & $\stackrel{I}{\Xi}$ & $\frac{y^{+}}{\underline{m}}$ & $\stackrel{\mathrm{r}}{\mathrm{I}}^{\mathrm{I}}$ & 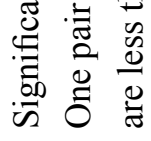 \\
\hline
\end{tabular}


We also report regression results from 1980 through 2006 to demonstrate the validity of the model. An empirical analysis of the data reveals that cash holdings have indeed been on the rise. In 1980, the ratio of cash to total assets was approximately 10 percent, and rose to 15 percent in 1999, a 50 percent increase. By the mid1980s the ratio was approximately 13 percent and fluctuated around that amount for the balance of the 1980s and 1990s. The mean of the cash ratio for each decade was 12.59 percent to 13.91 percent respectively (see Table 3, Panels A and B). However, the 2000 s saw increases in the ratios that ranged from approximately 15 percent to 21 percent except for 2009 when the ratio dipped to approximately 13 percent. The mean ratio of cash to total assets was approaching 19 percent for the period 20002006 (Table 3, Panel C). Data for the mean value of each variable in Equation 1 is provided in Table 3 for each period.

Table 3

Descriptive Data

For the periods 1980 to 1989, 1990 to1999 and 2000-2006

(Variable definitions follow Equation (1) in the text)

Panel A (the 1980s; n = 2253 Avg.)

\begin{tabular}{|l|c|c|c|c|}
\hline \multicolumn{1}{|c|}{ Variable } & Mean & $\begin{array}{c}\text { Standard } \\
\text { Deviation }\end{array}$ & Minimum & Maximum \\
\hline CashRatio $_{t}$ & 0.1259 & 0.1399 & 0.0000 & 0.9521 \\
\hline CashRatio $_{t-1}$ & 0.1259 & 0.1399 & 0.0000 & 0.09418 \\
\hline$\Delta \mathrm{REC}_{\mathrm{t}-1}$ & 0.1279 & 0.1420 & 0.0001 & 0.9418 \\
\hline$\Delta \mathrm{INV}_{\mathrm{t}-1}$ & -0.0242 & 0.0793 & -0.5837 & 1.1602 \\
\hline$\Delta \mathrm{AP}_{\mathrm{t}-1}$ & -0.0196 & 0.0765 & -0.5247 & 1.1403 \\
\hline$\Delta \mathrm{CFL}_{\mathrm{t}-1}$ & 0.0380 & 0.7358 & -22.0486 & 0.9760 \\
\hline $\mathrm{LTA}_{\mathrm{t}-1}$ & 0.0523 & 0.2354 & -1.5507 & 4.9707 \\
\hline $\mathrm{MKTBK}_{\mathrm{t}-1}$ & 3.6131 & 2.3106 & -3.2815 & 11.3218 \\
\hline $\mathrm{DR}_{\mathrm{t}-1}$ & 2.4835 & 12.3571 & -145.7708 & 441.6951 \\
\hline
\end{tabular}


Panel B (the 1990s; $n=2549$ Avg.)

\begin{tabular}{|l|c|c|c|c|}
\hline \multicolumn{1}{|c|}{ Variable } & Mean & $\begin{array}{c}\text { Standard } \\
\text { Deviation }\end{array}$ & Minimum & Maximum \\
\hline CashRatio $_{\mathrm{t}}$ & 0.1391 & 0.1656 & 0.0000 & 0.9818 \\
\hline CashRatio $_{\mathrm{t}-1}$ & 0.1421 & 0.1678 & 0.0000 & 0.9799 \\
\hline$\Delta \mathrm{REC}_{\mathrm{t}-1}$ & -0.0217 & 0.0847 & -0.6243 & 1.3263 \\
\hline$\Delta \mathrm{INV}_{\mathrm{t}-1}$ & -0.0138 & 0.0724 & -0.4633 & 1.3770 \\
\hline$\Delta \mathrm{AP}_{\mathrm{t}-1}$ & 0.0167 & 1.3072 & -50.1438 & 0.9908 \\
\hline$\Delta \mathrm{CFL}_{\mathrm{t}-1}$ & 0.0669 & 0.5750 & -4.3942 & 21.2730 \\
\hline $\mathrm{LTA}_{\mathrm{t}-1}$ & 4.1753 & 2.3964 & -4.3635 & 11.4492 \\
\hline $\mathrm{MKTBK}_{\mathrm{t}-1}$ & 2.9639 & 19.4108 & -498.4981 & 538.2716 \\
\hline $\mathrm{DR}_{\mathrm{t}-1}$ & 0.1657 & 0.2020 & 0.0000 & 3.8145 \\
\hline
\end{tabular}

Panel C (2000-2006; $\mathrm{n}=2724$ Avg.)

\begin{tabular}{|l|c|c|c|c|}
\hline \multicolumn{1}{|c|}{ Variable } & Mean & $\begin{array}{c}\text { Standard } \\
\text { Deviation }\end{array}$ & Minimum & Maximum \\
\hline CashRatio $_{\mathrm{t}}$ & 0.1858 & 0.1994 & 0.0000 & 0.9785 \\
\hline CashRatio $_{\mathrm{t}-1}$ & 0.1889 & 0.2058 & 0.0000 & 0.9658 \\
\hline$\Delta \mathrm{REC}_{\mathrm{t}-1}$ & -0.0013 & 0.2690 & -0.5954 & 12.9568 \\
\hline$\Delta \mathrm{INV}_{\mathrm{t}-1}$ & -0.0023 & 0.1637 & -0.4521 & 7.1733 \\
\hline$\Delta \mathrm{AP}_{\mathrm{t}-1}$ & 0.0176 & 2.1043 & -61.5795 & 71.8166 \\
\hline$\Delta \mathrm{CFL}_{\mathrm{t}-1}$ & 0.0410 & 2.8816 & -63.7795 & 111.1420 \\
\hline $\mathrm{LTA}_{\mathrm{t}-1}$ & 5.1961 & 2.5609 & -7.7573 & 12.2286 \\
\hline $\mathrm{MKTBK}_{\mathrm{t}-1}$ & 2.9189 & 65.6904 & -1526.3992 & 2338.4568 \\
\hline $\mathrm{DR}_{\mathrm{t}-1}$ & 0.1875 & 0.3471 & 0.0000 & 10.6921 \\
\hline
\end{tabular}

Consistent with the findings of Bates et al. (2009) of increasing cash holdings, we find evidence that companies progressively held more cash relative to their total assets. Bates reports a doubling of the cash to assets ratio from 1980 to 2006. Our findings are very similar. Thus, the ability to accurately forecast cash holdings may become more significant as the ratio of cash holdings increases.

We begin our analysis by testing the forecasting model over the periods of the 1980s, 1990s and 2000 to 2006 (Table 4). A regression is run for each year and then averaged for the period; accordingly, the results for each period are expressed as a mean for that period. The results are generally consistent over the periods with the 
firm operating variables remaining relatively static in terms of their predictability ( $\alpha$ $=.01$ ). One financing variable (market-to-book) is not significant, while long-term debt to total assets is significant $(\alpha=.10)$ for the $1980 \mathrm{~s}$, but is not significant for the remaining periods. The overall results are relatively constant in spite of fluctuations in business cycles over the 26 year period. Further, the adjusted $\mathrm{R}^{2}$ for each regression, and the periods, is relatively constant (adjusted $\mathrm{R}^{2}$ is between .87032 and .9010) for the three periods reported. From these results, we conclude that our cash forecasting model presents a successful cause and effect relation.

Table 4

Summary of Regression Coefficients for Equation (1)

For the periods 1980 to 1989, 1990 to1999 and 2000-2006

\begin{tabular}{|c|c|c|c|}
\hline & $\begin{array}{c}1980-1989 \\
(n=2263 \text { Avg.) }\end{array}$ & $\begin{array}{c}1990-1999 \\
(n=2549 \text { Avg.) }\end{array}$ & $\begin{array}{c}2000-2006 \\
(n=2724 \text { Avg.) }\end{array}$ \\
\hline Variable & Coefficient & Coefficient & Coefficient \\
\hline CashRatio $_{t-1}$ & $0.83212^{*}$ & $0.84003^{*}$ & $0.8614^{*}$ \\
\hline$\triangle \mathrm{REC}_{\mathrm{t}-1}$ & $0.18499^{*}$ & $0.09243^{*}$ & $-0.2027^{\star}$ \\
\hline$\Delta I N V_{t-1}$ & $0.23392^{*}$ & $0.14983^{*}$ & $-0.2369^{*}$ \\
\hline$\Delta \mathrm{AP}_{\mathrm{t}-1}$ & $0.03585^{\star}$ & $0.02075^{\star}$ & $0.2198^{\star}$ \\
\hline$\Delta \mathrm{CFL}_{\mathrm{t}-1}$ & $0.30325^{\star}$ & $0.16627^{\star}$ & $0.2249^{*}$ \\
\hline$L T A_{t-1}$ & $0.00314^{*}$ & $0.00245^{*}$ & $0.0024^{*}$ \\
\hline MKTBK $_{\mathrm{t}-1}$ & -0.00026 & 0.00022 & 0.0000 \\
\hline $\mathrm{DR}_{\mathrm{t}-1}$ & $-0.01587 \&$ & -0.00536 & -0.0056 \\
\hline Adj. $R^{2}$ & 0.88888 & 0.87032 & 0.9010 \\
\hline
\end{tabular}

Significance levels are $*=.01, \&=.10$

CashRatio $_{\mathrm{t}}=\mathrm{a}_{0}$ CashRatio $_{\mathrm{t}-1}+\mathrm{b}_{1} \Delta \mathrm{REC}_{\mathrm{t}-1}+\mathrm{b}_{2} \Delta \mathrm{INV}_{\mathrm{t}-1}+\mathrm{b}_{3} \Delta \mathrm{AP}_{\mathrm{t}-1}+\mathrm{b}_{4} \Delta \mathrm{CFL}_{\mathrm{t}-1}$

Where:

$$
+\mathrm{b}_{5} \mathrm{LTA}_{\mathrm{t}-1}+\mathrm{b}_{6} \text { MKTBKA }_{\mathrm{t}-1}+\mathrm{b}_{7} \mathrm{DR}_{\mathrm{t}-1}+\mathrm{e}_{\mathrm{t}}
$$

CashRatio $_{\mathrm{t}}=$ cash at time $\mathrm{t}$ divided by total assets $\left(\mathrm{ta}_{\mathrm{t}}\right)$ at time $\mathrm{t}$,

$\Delta \mathrm{REC}_{\mathrm{t}-1}=$ scaled change in receivables in year $\mathrm{t}-1$

$$
\text { (i.e., }\left(-\mathrm{REC}_{\mathrm{t}-1}+\mathrm{REC}_{\mathrm{t}-2} / \mathrm{ta}_{\mathrm{t}-1}\right) \text {, }
$$

$\Delta \mathrm{INV}_{\mathrm{t}-1}=$ scaled change in inventories in year $\mathrm{t}-1$

$$
\text { (i.e., }\left(-\mathrm{INV}_{\mathrm{t}-1}+\mathrm{INV}_{\mathrm{t}-2} / \mathrm{ta}_{\mathrm{t}-1}\right) \text { ), }
$$


$\Delta \mathrm{AP}_{\mathrm{t}-1}=$ scaled change in accounts payable and accrued liabilities in year t-1 (i.e., $\left.\left(\mathrm{AP}_{\mathrm{t}-1}-\mathrm{AP}_{\mathrm{t}-2} / \mathrm{ta}_{\mathrm{t}-1}\right)\right)$,

$\Delta \mathrm{CFL}_{\mathrm{t}-1}=$ cash change in year $\mathrm{t}-1$ less $\mathrm{REC}_{\mathrm{t}-1}, \mathrm{INV}_{\mathrm{t}-1}$, and $\mathrm{AP}_{\mathrm{t}-1}$ which is then scaled by ta $\mathrm{t}_{\mathrm{t}-1}$,

$\operatorname{LTA}_{\mathrm{t}-1}=\log \left(\mathrm{TA}_{\mathrm{t}-1}-\mathrm{CA}_{\mathrm{t}-1}-\mathrm{REC}_{\mathrm{t}-1}-\mathrm{INV}_{\mathrm{t}-1}\right)$,

MKTBK $_{t-1}=$ the stock market value in year $\mathrm{t}-1 /$ book value in year $\mathrm{t}-1$,

$\mathrm{DR}_{\mathrm{t}-1} \quad=$ the long term debt in year $\mathrm{t}-1 /$ tat- 1 , and

$\mathrm{e}_{\mathrm{t}} \quad=$ error in period $\mathrm{t}$.

Note: Regressions were run for each year of data and we then computed averages for each decade. We present the averages for ease of exposition.

The next step in our analysis focuses on the ability to forecast the ratio of cash to total assets immediately before, during and after the market collapse of 2008 . Annual results for 2007, 2008 and 2009 are presented in Table 5. For the period 2000 to 2006 (see Table 4) and the specific years under review (see Table 5), we find the model still performs well with high adjusted $\mathrm{R}^{2}$ 's, albeit with a couple of minor exceptions.

Consistent with our prior findings, the operating variables are generally significant ( $\alpha=.01$ ) for 2007 and 2008. The only exception is the long-term asset $\left(\mathrm{LTA}_{\mathrm{t}-1}\right)$ measure which is significant at $\alpha=.10$ for 2008 . The financing variable (market-to-book) generally does not have predictive value at a statistically significant level. However, the debt variable is significant for 2007 and $2009(\alpha=.01)$. The most interesting result for both 2007 and 2008 concerns the adjusted $\mathrm{R}^{2}$. The adjusted $\mathrm{R}^{2}$ for each year is approximately .97 , an increase of about 10 percent over our previous results. This result may be attributed to precautionary control of cash balances by firms during a period of turbulent economic circumstances.

After the market collapse in 2008, the predictive ability of the model for 2009 shifts with respect to the explanatory power of the operating and financing variables (see Table 5). The lagged cash coefficient (CashRatio ${ }_{t-1}$ ) drops from 2008 to 2009 (.90 to .69) while remaining significant $(\alpha=.01)$. However, the operating cycle variables of receivables and inventory are no longer significant at conventional levels. Further, the debt variable is now significant and is negatively associated with the dependent variable (this occurs for both 2007 and 2009, $\alpha=.01$ ). This result suggests that debt issues became more important with the general decline in overall business activities. The other interesting occurrence for 2009 is the adjusted $\mathrm{R}^{2}$. Following the sharp increase in 2007 and 2008, this statistic drops back to the general level found 
over the three base periods. Thus, it appears that the crisis of 2008 disrupted firms' operating cycle activities, and the normal patterns were altered, at least temporarily.

With respect to the research hypothesis, our findings reflect only weak evidence to reject the null. Specifically, we find that the coefficients on operating characteristics are potentially sensitive to serious changes in economic circumstances. However, the general explanatory power of the model is maintained relative to the historical norm.

Table 5

Summary of Regression Coefficients for Equation (1)

For the years 2007, 2008 and 2009

\begin{tabular}{|c|c|c|c|}
\hline & $2007(n=1982)$ & $2008(n=1639)$ & $2009(n=608)$ \\
\hline Variable & Coefficient & Coefficient & Coefficient \\
\hline CashRatio $_{\mathrm{t}-1}$ & $0.84851^{*}$ & $0.90152^{*}$ & $0.68858^{*}$ \\
\hline$\triangle \mathrm{REC}_{\mathrm{t}-1}$ & $0.14709^{\star}$ & $-0.63241^{*}$ & 0.04083 \\
\hline$\Delta I N V_{t-1}$ & $0.19398^{*}$ & $-0.64777^{\star}$ & 0.05899 \\
\hline$\Delta \mathrm{AP}_{\mathrm{t}-1}$ & $0.49313^{\star}$ & $0.59121^{*}$ & $0.02904 \&$ \\
\hline$\Delta \mathrm{CFL}_{\mathrm{t}-1}$ & $0.52737^{\star}$ & $0.61728^{*}$ & $0.39384^{*}$ \\
\hline $\mathrm{LTA}_{\mathrm{t}-1}$ & $0.00141^{*}$ & $0.00040 \&$ & $0.00604^{*}$ \\
\hline $\mathrm{MKTBK}_{\mathrm{t}-1}$ & -0.00005 & -0.00002 & -0.00038 \\
\hline $\mathrm{DR}_{\mathrm{t}-1}$ & $-0.02957^{\star}$ & 0.00458 & $-0.06989^{*}$ \\
\hline Adj. $R^{2}$ & 0.9677 & 0.96850 & 0.8861 \\
\hline
\end{tabular}

Significance levels are $*=.01, \&=.10$

CashRatio $_{\mathrm{t}}=\mathrm{a}_{0}$ CashRatio $_{\mathrm{t}-1}+\mathrm{b}_{1} \Delta \mathrm{REC}_{\mathrm{t}-1}+\mathrm{b}_{2} \Delta \mathrm{INV}_{\mathrm{t}-1}+\mathrm{b}_{3} \Delta \mathrm{AP}_{\mathrm{t}-1}+\mathrm{b}_{4} \Delta \mathrm{CFL}_{\mathrm{t}-1}$ $+\mathrm{b}_{5} \mathrm{LTA}_{\mathrm{t}-1}+\mathrm{b}_{6} \mathrm{MKTBKA}_{\mathrm{t}-1}+\mathrm{b}_{7} \mathrm{DR}_{\mathrm{t}-1}+\mathrm{e}_{\mathrm{t}}$

Where:

CashRatio $_{\mathrm{t}}=$ cash at time $\mathrm{t}$ divided by total assets $\left(\mathrm{ta}_{\mathrm{t}}\right)$ at time $\mathrm{t}$,

$\Delta \mathrm{REC}_{\mathrm{t}-1}=$ scaled change in receivables in year $\mathrm{t}-1$

(i.e., $\left(-\mathrm{REC}_{\mathrm{t}-1}+\mathrm{REC}_{\mathrm{t}-2} / \mathrm{ta}_{\mathrm{t}-1}\right)$,

$\Delta \mathrm{INV}_{\mathrm{t}-1} \quad=$ scaled change in inventories in year $\mathrm{t}-1$

(i.e., $\left(-\mathrm{INV}_{\mathrm{t}-1}+\mathrm{INV}_{\mathrm{t}-2} / \mathrm{ta}_{\mathrm{t}-1}\right)$ ),

$\Delta \mathrm{AP}_{\mathrm{t}-1} \quad=$ scaled change in accounts payable and accrued liabilities in year t-1 (i.e., $\left(\mathrm{AP}_{\mathrm{t}-1}-\mathrm{AP}_{\mathrm{t}-2} / \mathrm{ta}_{\mathrm{t}-1}\right)$ ),

$\Delta \mathrm{CFL}_{\mathrm{t}-1} \quad=$ cash change in year $\mathrm{t}-1$ less $\mathrm{REC}_{\mathrm{t}-1}, \mathrm{INV}_{\mathrm{t}-1}$, and $\mathrm{AP}_{\mathrm{t}-1}$ which is then scaled by $\mathrm{ta}_{\mathrm{t}-1}$, 
$\operatorname{LTA}_{\mathrm{t}-1}=\log \left(\mathrm{TA}_{\mathrm{t}-1}-\mathrm{CA}_{\mathrm{t}-1}-\mathrm{REC}_{\mathrm{t}-1}-\mathrm{INV}_{\mathrm{t}-1}\right)$,

$\mathrm{MKTBK}_{\mathrm{t}-1}=$ the stock market value in year $\mathrm{t}-1 /$ book value in year $\mathrm{t}-1$,

$\mathrm{DR}_{\mathrm{t}-1}=$ the long term debt in year $\mathrm{t}-1 /$ tat -1 , and

$\mathrm{e}_{\mathrm{t}} \quad=$ error in period $\mathrm{t}$.

Note: Variance inflation statistics (VIF) were computed on the individual 2007, 2008 and 2009 regressions as a multicollinearity check.

\section{CONCLUSIONS}

This study examines the ability to forecast cash holdings pre and post the 2008 market crash. The main conclusions are two-fold: (1) we find that firm specific variables provide a model with enhanced forecasting qualities, and (2) cash forecasting is potentially sensitive to changing economic circumstances.

First, in contrast to Bates et al. (2009) and Ozkan and Ozkan (2004), who used independent variables that were general in nature, we use firm specific variables based on a cash flow statement model. We report an adjusted $\mathrm{R}^{2}$ at .88 (or higher) over the three decades analyzed. Ozkan reports an adjusted $\mathrm{R}^{2}$ at .25 , and Bates reports an adjusted $\mathrm{R}^{2}$ that ranged from .199 to .459 . These results suggest that firm specific variables based on the cash flow statement approach are more effective than a mix of both firm and general economic variables. Unlike Harford (1999) or Bates et al. (2009), we find no support for the market-to-book variable in any of the sampled periods.

Second, our model is robust before the 2008 crisis, and remains robust after the event. However, the operating variables in the model declined in significance following the market problems, while the financing variables took on added importance. Thus, investors wishing to rely on cash forecasting as a tool for decision making are advised to use a comprehensive firm specific model.

Future research could isolate industry effects, other significant events, international effects and investor behavior. Corporate governance issues as they relate to cash forecasting is also an important issue which we do not address.

Our research demonstrates a successful cash forecasting model which is stable across time periods. Thus, with the growing emphasis of cash as firms increase their cash holdings, our model demonstrates an effective tool in the firm valuation process. This finding is consistent with the autoregressive theory reported by Opler et al. (1999). 


\section{REFERENCES}

Bates, T. W., Kahle, K. M., \& Stulz, R. M. (2009). Why Do U.S. Firms Hold So Much More Cash than They Used To?. The Journal of Finance, 64(5), 19852021.

Bleakley, F. (1995). Awash in Cash. The Wall Street Journal (October 16) A1 \& A9. Fazzari, S. M., Hubbard, R., Petersen, B. C., Blinder, A. S., \& Poterba, J. M. (1988). Financing Constraints and Corporate Investment. Brookings Papers on Economic Activity, 1998(1), 141-195.

Grinblatt, M. \& S. Titman (2001). Financial Markets and Corporate Strategy. (2Ed.). New York, NY: McGraw Hill.

Harford, J. (1999). Corporate Cash Reserves and Acquisitions. Journal of Finance, 54(6), 1969-1997.

Jensen, M. C. (1986). Agency Costs of Free Cash Flow, Corporate Finance, and Takeovers. The American Economic Review, 76(2), 323-329.

John, T. A. (1993). Accounting Measures of Corporate Liquidity, Leverage, and Costs of Financial Distress. Financial Management, 22(3), 91-100.

Kennedy, P. (2003). A Guide to Econometrics. Cambridge, Mass: MIT Press, 2003. Kim, C., Mauer, D. C., \& Sherman, A. E. (1998). The Determinants of Corporate Liquidity: Theory and Evidence. The Journal of Financial and Quantitative Analysis, 33(3), 335-359.

Mikkelson, W. H., \& Partch, M. (2003). Do Persistent Large Cash Reserves Hinder Performance? Journal of Financial and Quantitative Analysis, 38(2), 275-294.

Morris, J. R. (1983). The Role of Cash Balances in Firm Valuation. Journal of Financial and Quantitative Analysis, 18(4), 533-545.

Opler, T., Pinkowitz, L., Stulz, R., \& Williamson, R. (1999). Determinants and Implications of Corporate Cash Holdings. Journal of Financial Economics, 52(1), 3-46.

Ozkan, A. \& Ozkan, N. (2004). Corporate cash holdings: An empirical investigation of UK companies. Journal of Banking \& Finance, 28(9), 2103-2134.

Reinhardt, A., Himelstein, L., Weber, J. (1997). 'An Enormous Temptation to Waste'. Business Week, 42-43.

Vickrey. D. \& Z. Swanson (1996). Forecasting Small Firm Cash Positions: An Assessment of the Predictive Ability of FASB 95 Disclosures. Journal of Accounting and Finance Research, 1(8).

Zwieg, J. (2009 March 14). Corporate-Cash Umbrellas: Too Big for this Storm? The Wall Street Journal- Eastern Edition. p. B1. 


\section{BIOGRAPHICAL SKETCH OF AUTHORS}

Dr. Richard Alltizer is a certified public accountant with more than 14 years of public accounting experience. Dr. Alltizer is active in several professional organizations including the AICPA, the AAA, as well as state and local organizations. In 1994, he earned a Ph.D. in Business Administration from the University of Oklahoma. Dr. Alltizer is published in numerous professional and academic journals.

Dr. Swanson CPA, ABV is an accounting professor at University of Central Oklahoma College of Business where he teaches financial and international accounting courses. His research focuses on capital markets and he has published more than 30 journal articles, numerous textbook supplements and a book. He is also active in AIS/XBRL studies. Previous to his academic career, he was an analyst in nonprofit and financial institutions. He received his Ph.D. from the University of Oklahoma in accounting with a supporting field of finance. 